\title{
Evaluasi Penggunaan Antibiotik Pada Pasien Ulkus Diabetikum di Instalasi Rawat Inap (IRNA) Penyakit Dalam Rsup Dr.M.Djamil Padang
}

(Evaluation of Antibiotic Usage Among Diabetic Foot Ulcer Patients In Internal Medicine Ward of Dr. M. Djamil Padang Hospital)

\author{
Yelly Oktavia Sari*, Dedy Almasdy, \& Anggun Fatimah \\ Departemen Farmakologi dan Farmasi Klinis, Fakultas Farmasi, Universitas Andalas
}

\begin{abstract}
A rationality of antibiotic usage is needed to reduce bacterial resistance, infection severity, minimize expenditures, and patient's length of stay among diabetic foot ulcer patients. The aimed of the study was to obtain an overview of demography and clinical characteristics, usage of antibiotics, appropriateness of antibiotic, and association between demography and clinical characteristics of clinical outcome and rationality of antibiotics usage. The prospective method is applied. A total of 28 diabetic foot ulcer patients in Internal Medicine Ward of Dr. M. Djamil Padang Hospital were met the inclusion criteria. The demography characteristics showed the majority of patient were females $(60,72 \%), 45-60$ years old $(46,44 \%)$. The clinical characteristics showed the majority of patiens have been suffered from diabetes $<10$ years old $(71,43 \%)$, length of stay $3-7$ days $(53,57 \%)$, suffered from foot ulcer $1-3$ months $(60,72 \%)$, severe infection (71,43\%), clinical outcome is improving (71,43\%). Overview of antibiotic usage showed majority was Ceftriaxone (13\%), Metronidazole (13\%), and combination of Ceftriaxone + Metronidazol $(26,1 \%)$ with appropriate indication (100\%), appropriate patient (100\%) appropriate drug $(89,28 \%)$, appropriate dosage regimen $(57,14 \%)$, and no potential of drugs interaction $(67,85 \%)$. Statistical analysis showed no significant correlation between demography and clinical characteristics values of clinical outcome and rationality antibiotics $(p>0,05)$. The study concluded that the usage of antibiotics among diabetic foot ulcer patients are irrational.
\end{abstract}

Keywords: diabetic foot ulcer; antibiotic; rational; clinical outcome.

ABSTRAK: Penggunaan antibiotik yang rasional sangat diperlukan untuk mengurangi terjadinya resistensi, tingkat keparahan penyakit, biaya pengobatan dan lama waktu perawatan bagi penderita infeksi ulkus diabetikum. Penelitian ini bertujuan untuk memperoleh gambaran karakteristik demografi dan klinis pasien ulkus diabetikum di Instalasi Rawat Inap (IRNA) Penyakit Dalam RSUP Dr. M. Djamil Padang, pola penggunaan antibiotik, ketepatan penggunaan antibiotik dan hubungannya terhadap clinical outcome dan rasionalitas antibiotik. Penelitian dilakukan secara prospektif. Sebanyak 28 pasien memenuhi kriteria inklusi. Karakteristik demografi menunjukkan mayoritas pasien adalah perempuan (60-72 \%), umur 45-60 tahun (46,44 \%). Karakteristik klinis pasien menunjukkan mayoritas pasien dengan lama rawatan 3-7 hari $(53,57 \%)$, riwayat tukak 1-3 bulan $(60,72 \%)$, infeksi berat (71,43\%), clinical outcome membaik (71,43\%). Pola penggunaan antibiotik tunggal terbanyak adalah Seftriakson (13\%), Metronidazol (13\%) dan kombinasi antibiotik Seftriakson + Metronidazol (26,1\%). Penilaian rasionalitas penggunaan antibiotik adalah tepat indikasi $(100 \%)$, tepat pasien $(100 \%)$, tepat obat $(89,28 \%)$, tepat regimen dosis $(57,14 \%)$ dan potensi interaksi obat $(67,85 \%)$. Berdasarkan analisa statistik, tidak ada hubungan yang bermakna antara karakteristik demografi dan klinis terhadap clinical outcome dan rasionalitas antibiotik $(p>0,05)$. Dapat disimpulkan bahwa penggunaan antibiotik pada pasien ulkus diabetikum belum rasional.

Kata kunci: ulkus diabetikum; antibiotik; rasional; clinical outcome.

\section{Pendahuluan}

Diabetes Melitus (DM) adalah penyakit yang ditandai dengan kadar glukosa darah yang melebihi normal atau hiperglikemia akibat tubuh kekurangan insulin baik absolut maupun relatif [1]. Menurut PERKENI (2015) Diabetes melitus merupakan suatu kelompok penyakit metabolik dengan karakteristik hiperglikemia yang terjadi karena kelainan sekresi insulin, kerja insulin atau kedua-duanya.
Bila hal ini dibiarkan tidak terkendali dapat terjadi berbagai komplikasi akut maupun kronik [2].

Diabetes melitus adalah kondisi seumur hidup yang merupakan salah satu penyebab utama kematian di dunia. Jumlah penderita diabetes melitus meningkat seiring dengan perubahan gaya hidup [3]. International of Diabetic Federation melaporkan jumlah penderita diabetes melitus di dunia pada
Access this article

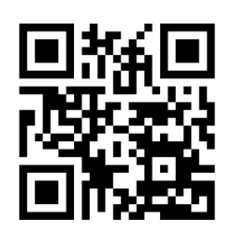


tahun 2015 mencapai 415 juta dan diperkirakan jumlah penderita akan meningkat mencapai 642 juta pada tahun 2040 [1]. Pada tahun 2003 WHO memperkirakan 194 juta atau sekitar 5,1\% dari 3,8 miliar jumlah penduduk dunia usia 20-79 tahun menderita DM dan diperkirakan jumlah penderita akan meningkat pada tahun 2025 menjadi 333 juta jiwa [4].

Menurut survei yang dilakukan oleh World Health Organization (WHO), jumlah penderita DM di Indonesia mencapai 8,4 juta jiwa pada tahun 2000 dan akan meningkat menjadi sekitar 21,3 juta jiwa pada tahun 2030 yang menjadikan Indonesia menduduki peringkat ke-4 dunia [4]. Prevalensi diabetes melitus di Indonesia berdasarkan Riset Kesehatan Dasar (RISKESDAS) tahun 2013 prevalensi diabetes melitus di Indonesia adalah 6,9\% [5].

Diabetes melitus disebut the great imitator karena menimbulkan berbagai komplikasi akut maupun kronik. Salah satu komplikasi kronik diabetes melitus adalah ulkus diabetikum. Ulkus diabetikum merupakan luka terbuka pada permukaan kulit karena adanya komplikasi makroangiopati sehingga terjadi vaskuler insufisiensi dan neuropati, serta dapat berkembang menjadi infeksi karena masuknya kuman atau bakteri dan adanya gula darah yang tinggi menjadi tempat yang strategis untuk pertumbuhan kuman [6].

Ulkus kaki adalah salah satu komplikasi utama diabetes melitus dimana pasien ulkus di kaki berisiko tinggi untuk amputasi dan kematian. Prevalensi pasien ulkus kaki diabetik (UKD) berkisar 41\% dari populasi umumnya, dengan prevalensi yang lebih tinggi pada manula. Sekitar 14$24 \%$ pasien UKD memerlukan amputasi dengan rekurensi $50 \%$ setelah tiga tahun [7]. Sekitar 15\% pasien diabetes mengalami tukak kaki dan 15-20\% dari ini memerlukan amputasi [8]. Amputasi kaki diabetik cenderung terjadi seiring dengan kenaikan tingkat kematian atau morbiditas dari waktu ke waktu. Peningkatan angka kejadian kematian diyakini menjadi 13\%-40\% setelah 1 tahun, 35\%-65\% setelah 3 tahun, dan 39\%-80\% setelah 5 tahun [9].

Untuk mengatasi masalah infeksi diperlukan pengobatan yang tepat, salah satunya menggunakan antibiotika. Antibiotika merupakan obat yang paling banyak digunakan pada infeksi yang disebabkan oleh bakteri. Konsekuensi yang tidak terhindari dari meluasnya penggunaan antibiotik yaitu munculnya resistensi terhadap antibiotik. Meskipun kesadaran akan konsekuensi dari penyalahgunaan antibiotik semakin meningkat, pemberian resep antibiotik yang berlebihan tetap terjadi, hal ini disebabkan oleh permintaan pasien, tekanan waktu pada dokter, dan ketidakpastian diagnosa [10].

Penggunaan antibiotik untuk penyakit infeksi secara tidak tepat dapat mengakibatkan tujuan terapi tidak tercapai. Intensitas penggunaan antibiotik yang relatif tinggi menimbulkan berbagai permasalahan dan merupakan ancaman global bagi kesehatan terutama resistensi bakteri terhadap antibiotik. Selain berdampak pada morbiditas dan mortalitas, juga memberi dampak negatif terhadap ekonomi dan sosial yang sangat tinggi. Resistensi ini menyebabkan dibutuhkannya antibiotik baru untuk mengatasi infeksi yang lama. Proses menemukan antibiotik baru untuk melanjutkan terapi yang efektif membutuhkan waktu yang lama dan biaya yang besar [11].

Berdasarkan data penelitian mengenai efektivitas antibiotik pada pasien ulkus kaki diabetik di SMF Ilmu Penyakit Dalam Riau, pemberian antibiotik untuk infeksi ulkus kaki diabetik efektif terhadap 78,94\% subjek penelitian dan antibiotik tidak efektif terhadap 21,05\% orang subjek penelitian dengan bakteri resisten terhadap semua jenis antibiotik [12]. Menurut penelitian Decroli tahun 2008 tentang profil ulkus diabetik dan penelitian Hatanta tahun 2013 tentang kajian penggunaan antibiotik pada pasien infeksi ulkus kaki diabetik di RSUP Dr. M. Djamil Padang, beberapa bakteri telah resisten terhadap antibiotik yang digunakan secara empiris seperti sefotaksim, seftriakson, dan siprofloksasin $[13,14]$.

Penelitian yang lain juga telah dilakukan pada bulan Juli - September 2017 oleh Nafilataini di IRNA Penyakit Dalam RSUP Dr. M. Djamil Padang mengenai evaluasi penggunaan antibiotik pada pasien ulkus diabetikum diperoleh ketepatan penggunaan antibiotik pada pasien adalah $88,46 \%$ tepat obat dan 30,76\% tepat dosis dengan hasil clinical outcome pasien menunjukkan 11 orang dari 26 orang pasien meninggal [15]. Berdasarkan hasil tersebut maka penggunaan antibiotika pada pasien ulkus diabetikum perlu diperhatikan. Sehingga perlu dilakukan studi lebih lanjut mengenai penggunaan antibiotik pada pasien ulkus diabetikum. Jenis antibiotik yang digunakan untuk mengobati infeksi harus tepat dan bijak karena mikroorganisme yang menginfeksi pasien penderita ulkus diabetikum sangat beragam. Ketepatan penggunaan antibiotik dalam pengobatan akan memberikan hasil terapi yang lebih baik, mengurangi angka resistensi antibiotik, kejadian amputasi, meningkatkan kualitas hidup pasien dan menurunkan tingkat kematian.

Tujuan penelitian ini untuk mengetahui bagaimana gambaran karakteristik demografi, karakteristik klinis, pola penggunaan antibiotik, ketepatan penggunaan antibiotik, hubungan karakteristik demografi dan karakteristik klinis terhadap clinical outcome dan kerasionalan penggunaan antibiotik pada pasien ulkus diabetikum di IRNA Penyakit Dalam RSUP Dr. M. Djamil Padang.

\section{Metode Penelitian}

\author{
Desain Studi \\ Penelitian ini dilakukan menggunakan metode \\ observasi bersifat deskriptif dengan pendekatan
}


prospektif.

\section{Sampel Penelitian}

Seluruh pasien ulkus diabetikum yang diberikan antibiotik di IRNA Penyakit Dalam RSUP Dr.M. Djamil Padang selama bulan Februari - April 2018

Jenis Data

Data yang diambil adalah data demografi, data klinis pasien, dan data antibiotik yang digunakan dalam terapi pasien ulkus diabetikum meliputi terapi empiris dan terapi definitif.

Analisis data

Data dianalisis secara kuantitatif dan kualitatif. Analisis kuantitatif menggunakan SPSS dengan uji Chi-Square untuk mengetahui karakteristik demografi dan karakteristik klinis terhadap clinical outcome pasien serta kerasionalan tehadap antibiotik. Analisa kualitatif dilakukan dengan mengkaji secara kualitatif terhadap ketepatan penggunaan obat secara rasional, meliputi: tepat indikasi, tepat pasien, tepat obat, tepat regimen dosis dan potensi interaksi obat..

\section{Hasil dan Diskusi}

Penelitian yang telah dilakukan mengenai Evaluasi Penggunaan Antibotik pada pasien ulkus diabetikum yang dirawat inap di IRNA Penyakit Dalam RSUP Dr. M. Djamil Padang diiperoleh 28 pasien yang memenuhi kriteria inklusi selama bulan Februari-April 2018.

Berdasarkan karakteristik demografis pasien ulkus diabetikum adalah 11 pasien laki-laki (39,28\%) dan 17 pasien perempuan $(60,72 \%)$. Hasil ini sejalan dengan penelitian yang telah dilakukan oleh Hastuti di RSUD Dr. Moewardi Surakarta 2008 dan Nafilataini di IRNA Penyakit Dalam RSUP Dr. M. Djamil Padang 2017 menunjukkan perempuan lebih banyak menderita ulkus diabetikum dibandingkan laki-laki. Berbeda dengan hasil penelitian yang dilakukan oleh Decroli di IRNA Penyakit Dalam RSUP Dr. M. Djamil Padang 2008 dimana penderita ulkus diabetikum lebih banyak pada laki-laki $[13,15,16]$. Menurut Perkumpulan Endrokrinologi Indonesia, prevalensi penyakit diabetes melitus lebih banyak terjadi pada perempuan sehingga ulkus diabetikum juga banyak terjadi pada perempuan [2].

Berdasarkan kelompok usia didapatkan hasil usia < 45 tahun sebanyak 14,28\%, usia 45-60 tahun sebanyak $46,44 \%$ dan usia $>60$ tahun sebanyak 39,28\%. Kelompok usia pasien ulkus diabetikum dominan pada rentang usia 45-60 tahun karena kejadian dan prevalensi ulkus diabetikum dapat meningkat seiring bertambahnya usia. Pada usia $>40$ tahun, prevalensi ulkus diabetik meningkat $3 \%$ dan 6\% pada usia $>60$ tahun [17]. Pada wanita dengan rentang usia menopause 45-65 tahun akan mempercepat penurunan produksi hormon esterogen didukung dengan adanya gangguan metabolik, gangguan kardiovaskular dan keganasan [18].

Selain itu, terjadi penurunan fungsi fisiologis tubuh karena proses penuaan dan penurunan sekresi insulin [19]. Sel kulit juga mengalami penurunan keelastisitasannya akibat menurunnya cairan vaskularisasi dikulit dan kelenjer lemak menyebabkan kulit yang tidak elastis akan mengurangi kemampuan regenerasi sel ketika luka dan memperlambat penyembuhan luka [20].

Hasil data penelitian pada status pekerjaan pasien didapatkan yang bekerja (46,43\%) dan tidak bekerja $(53,57 \%)$. Hasil penelitian menunjukkan kejadian diabetes dan komplikaisnya lebih banyak terjadi pada pasien yang tidak bekerja karena rendahnya aktivitas fisik dibandingkan mereka yang bekerja terutama ibu rumah tangga. Selain itu aktivitas perempuan yang hanya dilakukan di rumah dan tanpa menggunakan alas kaki turut mempertinggi faktor resiko terjadinya ulkus diabetik pada perempuan [21].

Sedangkan berdasarkan data hasil tingkat pendidikan didapatkan 7,14\% berpendidikan SD, 14,28\% berpendidikan SMP, 67,86\% berpendidikan SMA dan 10,72\% berpendidikan akademi atau sarjana. Tingkat pendidikan SMA merupakan tingkat pendidikan terbanyak pada pasien ulkus diabetikum. Semakin rendah pendidikan maka semakin rendah tingkat kesadaran terhadap kesehatan yang berpengaruh terhadap memburuknya status kesehatan dimana pasien dengan tingkat pendidikan rendah cenderung tidak mengetahui gejala-gejala, faktor resiko dan pencegahan dari diabetes melitus dan komplikasi yang ditimbulkan [22]. Selain itu, adanya pengetahuan dari berbagai sumber informasi yang memadai memungkinkan pasien lebih mengenali masalah gejala dan hal apa yang harus dilakukan.

Berdasarkan data karakteristik klinis pada pasien ulkus diabetikum diperoleh lama menderita DM $<10$ tahun sebanyak $71,43 \%$ dan $\geq 10$ tahun sebanyak $28,57 \%$. Pasien dengan lama penderita DM terbanyak terjadi pada waktu $<10$ tahun. Hasil ini sejalan dengan hasil penelitian Decroli tahun 2008 dan Nafilataini tahun 2017 di IRNA Penyakit Dalam RSUP Dr. M. Djamil Padang dimana distribusi lama menderita diabetes melitus terbanyak yang menyebabkan ulkus terjadi $<10$ tahun [14,17]. Lama menderita diabetes berkaitan dengan kadar glukosa darah yang tidak terkendali yang dapat menyebabkan komplikasi 
Tabel 1. Karakteristik demografi pasien ulkus diabetikum

\begin{tabular}{|lcc|}
\hline \multicolumn{1}{|c|}{ Kategori } & Jumlah Pasien & (\%) \\
\hline Jenis kelamin & & \\
- Laki-laki & 11 & $39,28 \%$ \\
- Perempuan & 17 & $60,72 \%$ \\
Total & $\mathbf{2 8}$ & $\mathbf{1 0 0} \%$ \\
Umur & & \\
- $<45$ tahun & 4 & $14,28 \%$ \\
- 45 - 60 tahun & 13 & $46,44 \%$ \\
- 60 tahun & 11 & $39,28 \%$ \\
Total & $\mathbf{2 8}$ & $\mathbf{1 0 0} \%$ \\
Pekerjaan & & \\
- Tidak bekerja & 15 & $53,57 \%$ \\
- Bekerja & 13 & $46,43 \%$ \\
Total & $\mathbf{2 8}$ & $\mathbf{1 0 0} \%$ \\
Pendidikan & & \\
- SD & 2 & $7,14 \%$ \\
- SMP & 4 & $14,28 \%$ \\
- SMA & 19 & $67,86 \%$ \\
- Akademi/Sarjana & 3 & $10,72 \%$ \\
Total & $\mathbf{2 8}$ & $\mathbf{1 0 0} \%$ \\
\hline
\end{tabular}

Tabel 2. Karakteristik klinis pasien ulkus diabetikum

\begin{tabular}{|c|c|c|}
\hline Kategori & Jumlah Pasien & (\%) \\
\hline \multicolumn{3}{|c|}{ Lama menderita DM } \\
\hline$-<10$ tahun & 20 & $71,43 \%$ \\
\hline$-\geq 10$ tahun & 8 & $28,57 \%$ \\
\hline Total & 28 & $100 \%$ \\
\hline \multicolumn{3}{|l|}{ Lama dirawat } \\
\hline$-<3$ hari & 4 & $14,29 \%$ \\
\hline - 3-7 hari & 15 & $53,57 \%$ \\
\hline - 8-14 hari & 8 & $28,57 \%$ \\
\hline - > 14 hari & 1 & $3,57 \%$ \\
\hline Total & 28 & $100 \%$ \\
\hline \multicolumn{3}{|l|}{ Riwayat tukak } \\
\hline$-<1$ bulan & 6 & $21,43 \%$ \\
\hline - 1-3 bulan & 17 & $60,72 \%$ \\
\hline$->3$ bulan & 5 & $17,85 \%$ \\
\hline Total & 28 & $100 \%$ \\
\hline \multicolumn{3}{|l|}{ Tingkat infeksi } \\
\hline - Sedang & 8 & $28,57 \%$ \\
\hline - Berat & 20 & $71,43 \%$ \\
\hline Total & 28 & $100 \%$ \\
\hline \multicolumn{3}{|l|}{ Clinical outcome } \\
\hline - Membaik & 20 & $71,43 \%$ \\
\hline - Memburuk & 1 & $3,57 \%$ \\
\hline - Meninggal & 7 & $25,00 \%$ \\
\hline Total & 28 & $100 \%$ \\
\hline
\end{tabular}


kronik sehingga dalam jangka waktu cukup lama akan menyebabkan kematian jaringan yang akan berkembang menjadi ulkus diabetikum [23].

Berdasarkan hasil lama masa rawat inap pasien ulkus diabetikum $<3$ hari sebesar 14,29\%, 3-7 hari sebesar 53, $57 \%, 8-14$ hari sebesar 28,57\% dan $>14$ hari sebesar $3.57 \%$. Masa rawat inap terbanyak pada rentang 3-7 hari karena rata-rata pasien yang dirawat mendapat rujukan. Lamanya masa perawatan dikarenakan kondisi pasien yang belum membaik dan mendapatkan perawatan kembali karena kambuhnya penyakit. Sedangkan masa rawat inap yang lebih singkat $<3$ hari karena kondisi pasien membaik dan selama perawatan pasien meninggal serta pasien pulang atas permintaan pasien dan keluarga pasien sendiri (pulang paksa).

Hasil riwayat tukak pasien ulkus diabetikum diperoleh riwayat tukak $<1$ bulan sebesar 7,15\%, 1 - 3 bulan sebesar $75 \%$ dan $>3$ bulan sebesar $17,85 \%$. Riwayat tukak terbesar dalam rentang $1-3$ bulan. Pasien dengan luka ulkus $>$ 3-4 minggu umumnya mempunyai infeksi luka yang lebih luas kerena tingginya tingkat keparahan infeksi, hal ini juga terkait dengan pengetahuan pasien dalam membersihkan luka untuk mencegah infeksi dan terjadinya infeksi yang lebih luas [6].

Data tingkat keparahan infeksi didapatkan infeksi sedang $(28,57 \%)$ dan infeksi berat (71,43\%). Infeksi berat menjadi tingkat infeksi terbanyak yang diderita pasien ulkus karena hasil pemeriksaan klinis pasien ketika masuk rumah sakit menunjukkan adanya tanda sepsis, seperti suhu tubuh $>38^{\circ} \mathrm{C}$ atau $<36^{\circ} \mathrm{C}$, denyut nadi $>90 \mathrm{x} /$ menit, laju pernafasan $>20 \mathrm{x} /$ menit, dan jumlah leukosit $>$ $12.000 \mathrm{sel} / \mu \mathrm{L}$ atau $<4000 \mathrm{sel} / \mu \mathrm{L}$ sesuai dengan klasifikasi PEDIS [6].

Berdasarkan kondisi pasien setelah keluar dari rumah sakit (clinical outcome) diperoleh data 20 pasien (71,43\%) membaik, 1 pasien (3,57\%) memburuk dan 7 pasien (25\%) meninggal. Kondisi pasien membaik karena penurunan tingkat keparah dari penyakit yang diderita pasien maupun komplikasi yang ditimbulkan. Selain itu, pasien juga mendapatkan perawatan kaki seperti debridement dan penanganan bedah dengan tujuan untuk penyembuhan luka secepat mungkin karena perbaikan dari ulkus kaki dapat menurunkan terjadinya amputasi dan kematian pasien diabetes [23]. Kondisi pasien memburuk karena peningkatan keparahan infeksi dan pasien pulang paksa atas keinginan pasien sendiri. Sedangkan kondisi pasien meninggal karena meningkatnya keparahan ulkus dan komplikasi penyakit lainnya yang diderita pasien.

Pemilihan antibiotik pada infeksi ulkus diabetik harus berdasarkan pada hasil kultur bakteri yang dilanjutkan dengan uji resistensi bakteri terhadap antibiotik. Data yang didapat dari hasil uji kultur bakteri dan resistensi antibiotik dijadikan sebagai dasar dilakukan terapi definitif. Hal ini dikarenakan pola bakteri dan resistensi antibiotik tiap daerah dan rumah sakit berbeda [24].

Pola penggunaan antibiotik pada pasien ulkus diabetikum di IRNA Penyakit Dalam RSUP DR.M. Djamil Padang, antibiotik empiris diberikan secara tunggal, kombinasi 2 antibiotik dan kombinasi 3 antibiotik. Pemberian antibiotik empiris dilakukan sebagai penanganan awal bagi pasien yang mengalami infeksi bakteri. Antibiotik tunggal yang banyak diresepkan pada pasien merupakan antibiotik golongan Sefalosporin generasi III dan Nitroimidazol yaitu Seftriakson (13\%) dan Metronidazol (13\%). Seftriakson diresepkan karena dapat menghambat sintesis dinding sel bakteri dimana aktivitasnya lebih aktif terhadap Enterobacteriaceae, termasuk strain yang memproduksi beta-laktamase [11]. Sedangkan Metronidazol merupakan antibiotik dengan mekanisme kerja obat yang aktif terhadap pembunuhan protozoa, hal ini menjadi pertimbangan yang paling mendasar dalam pemilihan antibiotik empiris [25]. Pemilihan antibiotik empiris harus tepat, kesalahan pemilihan akan terkait dengan kejadiaan resistensi antibiotik.

Pola terapi penggunaan kombinasi 2 antibiotik paling banyak diresepkan adalah golongan Sefalosporin generasi III dan Nitroimidazol yaitu Seftriakson dan Metronidazol $(26,1 \%)$ dimana pemilihan terapi infeksi ulkus diabetik derajat sedang sampai berat dapat diberikan antibiotik golongan Ampisillin Sulbaktam atau Sefalosporin generasiIII yang dikombinasi dengan Metronidazol [6]. Kombinasi antibiotik golongan Sefalosporin dan Metronidazol efektif sebagai terapi empiris pada infeksi tungkai bawah karena akan memperluas spektrum aktivitas antibakteri sehingga dapat melawan bakteri gram positif dan negatif serta bakteri anaerob [26].

Pada pola terapi penggunaan kombinasi 3 antibiotik banyak diresepkan golongan Sefalosporin generasi-III, Fluorokuinolon, dan Nitroimidazol yaitu kombinasi Seftriakson, Levofloksasin, dan Metronidazol (4,3\%), kombinasi Seftriakson, Siprofloksasin, dan Metronidazol $(4,3 \%)$, serta kombinasi Seftazidim, Levofloksasin, dan Metronidazol (4,3\%). Selain penggunaan antibiotik golongan Sefalosporin dan Nitroimidazol, pemilihan antibiotik golongan Fluorokuinolon sebagai kombinasi terapi juga diperhitungkan. Antibiotik golongan Flurokuinolon bekerja dengan menghambat sintesa protein dan asam nukleat pada bakteri. Flurokuinolon dapat digunakan untuk infeksi yang disebabkan oleh Gonokokus, Shigella, E. coli, Salmonella, Haemophilus, Moraxella 
Tabel 3. Pola penggunaan antibiotik pada pasien ulkus diabetikum

\begin{tabular}{|c|c|c|c|c|}
\hline \multirow[t]{2}{*}{ No } & \multirow[t]{2}{*}{ Penggunaan Antibiotik } & \multirow[t]{2}{*}{ Nama Antibiotik } & \multicolumn{2}{|c|}{ Jumlah n \% } \\
\hline & & & n & $\%$ \\
\hline \multirow{3}{*}{1} & \multirow{3}{*}{ Antibiotik Tunggal } & Seftriakson & 6 & $13,0 \%$ \\
\hline & & Sefotaksim & 1 & $2,2 \%$ \\
\hline & & Metronidazol & 6 & $13,0 \%$ \\
\hline \multirow{8}{*}{2} & \multirow{8}{*}{ Kombinasi 2 Antibiotik } & Seftriakson + Metronidazol & 12 & $26,1 \%$ \\
\hline & & Seftriakson + Ciprofloksasin & 1 & $2,2 \%$ \\
\hline & & Seftriakson + Levofloksasin & 1 & $2,2 \%$ \\
\hline & & Seftazidim + Metronidazol & 1 & $2,2 \%$ \\
\hline & & Sefoperazon + Levofloksasin & 1 & $2,2 \%$ \\
\hline & & Levofloksasin + Metronidazol & 1 & $2,2 \%$ \\
\hline & & Levofloksasin + Meropenem & 1 & $2,2 \%$ \\
\hline & & Metronidazol + Meropenem & 3 & $6,6 \%$ \\
\hline \multirow{8}{*}{3} & \multirow{8}{*}{ Kombinasi 3 Antibiotik } & Seftriakson + Levofloksasin + Metronidazol & 2 & $4,3 \%$ \\
\hline & & Seftriakson + Ciprofloksasin + Levofloksasin & 1 & $2,2 \%$ \\
\hline & & Seftriakson + Ciprofloksasin + Metronidazol & 2 & $4,3 \%$ \\
\hline & & Seftazidim + Ciprofloksasin + Metronidazol & 1 & $2,2 \%$ \\
\hline & & Seftazidim + Levofloksasin + Metronidazol & 2 & $4,3 \%$ \\
\hline & & Ciprofloksasin + Meropenem + Metronidazol & 2 & $4,3 \%$ \\
\hline & & Levofloksasin + Meropenem + Metronidazol & 2 & $4,3 \%$ \\
\hline & & & 46 & $100 \%$ \\
\hline
\end{tabular}

Tabel 4. Kerasionalan antibiotik

\begin{tabular}{|cccc|}
\hline No & Kerasionalan & Jumlah pasien & Jumlah (\%) \\
\hline 1 & Tepat Indikasi & 28 pasien & $100 \%$ \\
2 & Tepat Pasien & 28 pasien & $100 \%$ \\
3 & Tepat Obat & 25 pasien & $89,28 \%$ \\
4 & Tepat Regimen Dosis & 16 pasien & $57,14 \%$ \\
5 & Potensi Interaksi Obat & 19 pasien & $67,85 \%$ \\
\hline
\end{tabular}

catarrhalis serta Enterobacteriaceae dan P. aeruginosa yang merupakan kelompok bakteri penginfeksi pada pasien penderita ulkus diabetikum [11].

Pemberian Siprofloksasin pada pasien ulkus diabetikum diindikasikan untuk infeksi jaringan lunak, tendon, tulang, dan infeksi yang disebabkan oleh bakteri yang banyak resisten terhadap antibiotik (multidrugresistant/MDR) seperti Pseudomonas sp [25]. Kombinasi golongan Sefalosporin generasi-III, Fluroquinolon, dan Nitroimidazol diharapkan mencapai target terapi yang lebih luas dan efek kerja yang maksimal karena mekanisme kerja obat ini melalui penghambatan sintesis DNA yang akan menghambat perkembangbiakan bakteri dan aktif terhadap pembunuhan protozoa sehingga menyebabkan kematian sel pada bakteri [27].

Selain itu, kombinasi golongan Flurokuinolon, Karbapenem dan Nitroimidazol juga menjadi pilihan dalam terapi empiris terutama untuk pasien dengan tingkat komplikasi sedang hingga berat yaitu Siprofloksasine, Meropenem, dan Metronidazol (4,3\%), Levofloksasine, Meropenem, dan Metronidazol (4,3\%). Golongan antibiotik karbapenem menjadi pilihan terapi tidak hanya untuk terapi empiris tetapi juga digunakan untuk terapi definitif yang diberikan setelah didapatkannya hasil kultur 
Tabel 5. Hubungan karakteristik demografi dan klinis terhadap clinical outcome

\begin{tabular}{|c|c|c|c|c|}
\hline \multirow[t]{2}{*}{ No } & \multirow[t]{2}{*}{ Karakteristik } & \multicolumn{2}{|c|}{ Clinical Outcome } & \multirow[t]{2}{*}{ Nilai P } \\
\hline & & Membaik & Memburuk / Meninggal & \\
\hline \multirow{3}{*}{1} & Jenis Kelamin & & & \multirow{3}{*}{$0,099^{b}$} \\
\hline & Laki-laki & 10 & 1 & \\
\hline & Perempuan & 10 & 7 & \\
\hline \multirow{3}{*}{2} & Umur & & & \multirow{3}{*}{$0,671^{b}$} \\
\hline & Dewasa & 13 & 4 & \\
\hline & Lansia & 7 & 4 & \\
\hline \multirow{3}{*}{3} & Status Pekerjaan & & & \multirow{3}{*}{$0,221^{b}$} \\
\hline & Bekerja & 11 & 2 & \\
\hline & Tidak Bekerja & 9 & 6 & \\
\hline \multirow{3}{*}{4} & Tingkat Pendidikan & & & \multirow{3}{*}{$1,000^{b}$} \\
\hline & Dasar & 4 & 2 & \\
\hline & Lanjut & 16 & 6 & \\
\hline \multirow{3}{*}{5} & Riwayat DM & & & \multirow{3}{*}{$1,000^{b}$} \\
\hline & $<10$ tahun & 14 & 6 & \\
\hline & $\geq 10$ tahun & 6 & 2 & \\
\hline \multirow{3}{*}{6} & Lama Dirawat & & & \multirow{3}{*}{$0,029^{b}$} \\
\hline & $\leq 7$ hari & 11 & 8 & \\
\hline & $>7$ hari & 9 & 0 & \\
\hline \multirow{3}{*}{7} & Riwayat Tukak & & & \multirow{3}{*}{$0,640^{b}$} \\
\hline & $<1$ bulan & 5 & 1 & \\
\hline & $\geq 1$ bulan & 15 & 7 & \\
\hline \multirow{3}{*}{8} & Tingkat Infeksi & & & \multirow{3}{*}{$0,651^{\mathrm{b}}$} \\
\hline & Sedang & 5 & 3 & \\
\hline & Berat & 15 & 5 & \\
\hline
\end{tabular}

a: Chi Square Test b: Fisher's Exact Test

bakteri dan uji sensitivitas bakteri terhadap resistensi antibiotik.

Meropenem merupakan antibiotik spektrum luas bekerja dengan menghambat sebagian besar bakteri gram positif, gram negatif, dan anaerob yang merupakan kelompok bakteri terbanyak penyebab infeksi pada pasien ulkus diabetikum [11]. Penelitian yang dilakukan oleh Decroli (2008), Hatanta (2013), dan Agistia (2017) di RSUP Dr. M. Djamil Padang menunjukan antibiotik meropenem masih memiliki sensitivitas yang tinggi [1214]. Hal tersebut juga didukung oleh hasil uji resistensi dan sensitivitas antibiotik pasien P7, P9, dan P10 dimana Meropenem terbukti tidak resistensi dan masih sensitif.

Dari hasil kultur bakteri yang dilakukan terhadap tiga pasien ulkus didapatkan Staphylococcus aureus dan
Staphylococcus coagulase sebagai bakteri penyebab infeksi. Pada uji sensitivitas dan resistensi antibiotik menunjukkan Seftriakson, Siprofloksasin, dan Sefotaksim yang digunakan untuk terapi empiris telah resisten. Peresepan Seftriakson dan Siprofloksasin masih banyak dilakukan sebagai terapi empiris dengan pertimbangan antibiotik masih sensitif pada pasien lainnya.

Keterbatasan hasil kultur bakteri dan uji sentitivitas antibiotik yang dilakukan menjadi penyebab dan pertimbangan dalam pemilihan antibiotik pada pasien ulkus. Pemberian antibiotik empiris lebih dari 3-4 hari tanpa adanya hasil kultur perlu diperhatikan terutama untuk antibiotik Seftriakson dan Siprofloksasin yang banyak diresepkan baik tunggal maupun kombinasi. Menurut penelitian Decroli (2008) tentang profil ulkus diabetik 
Tabel 6. Hubungan karakteristik demografi dan klinis terhadap rasionalitas antibiotik

\begin{tabular}{|c|c|c|c|c|}
\hline \multirow[t]{2}{*}{ No } & \multirow[t]{2}{*}{ Karakteristik } & \multicolumn{2}{|c|}{ Clinical Outcome } & \multirow[t]{2}{*}{ Nilai P } \\
\hline & & Membaik & Memburuk / Meninggal & \\
\hline \multirow{3}{*}{1} & Jenis Kelamin & & & \multirow{3}{*}{0,488} \\
\hline & Laki-laki & 6 & 5 & \\
\hline & Perempuan & 7 & 10 & \\
\hline \multirow{3}{*}{2} & Umur & & & \multirow{3}{*}{0,390} \\
\hline & Dewasa & 9 & 8 & \\
\hline & Lansia & 4 & 7 & \\
\hline \multirow{3}{*}{3} & Status Pekerjaan & & & \multirow{3}{*}{0,431} \\
\hline & Bekerja & 5 & 8 & \\
\hline & Tidak Bekerja & 8 & 7 & \\
\hline \multirow{3}{*}{4} & Tingkat Pendidikan & & & \multirow{3}{*}{1,000} \\
\hline & Dasar & 3 & 3 & \\
\hline & Lanjut & 10 & 12 & \\
\hline \multirow{3}{*}{5} & Riwayat DM & & & \multirow{3}{*}{1,000} \\
\hline & $<10$ tahun & 9 & 11 & \\
\hline & $\geq 10$ tahun & 4 & 4 & \\
\hline \multirow{3}{*}{6} & Lama Dirawat & & & \multirow{3}{*}{0,114} \\
\hline & $\leq 7$ hari & 11 & 8 & \\
\hline & $>7$ hari & 2 & 7 & \\
\hline \multirow{3}{*}{7} & Riwayat Tukak & & & \multirow{3}{*}{0,655} \\
\hline & $<1$ bulan & 2 & 4 & \\
\hline & $\geq 1$ bulan & 11 & 11 & \\
\hline \multirow{3}{*}{8} & Tingkat Infeksi & & & \multirow{3}{*}{0,686} \\
\hline & Sedang & 3 & 5 & \\
\hline & Berat & 10 & 10 & \\
\hline \multirow{3}{*}{9} & Clinical Outcome & & & \multirow{3}{*}{$0,410^{b}$} \\
\hline & Membaik & 8 & 12 & \\
\hline & Memburuk/Meninggal & 5 & 3 & \\
\hline
\end{tabular}

a: Chi Square Test b: Fisher's Exact Test

dan penelitian Hatanta (2013) tentang kajian penggunaan antibiotik pada pasien infeksi ulkus kaki diabetik di RSUP Dr. M. Djamil Padang, beberapa bakteri telah resisten terhadap antibiotik yang digunakan secara empiris seperti Sefotaksim, Seftriakson, dan Siprofloksasine [13,14]. Pemilihan antibiotik untuk pasien ulkus dilakukan secara hati-hati demi tercapainya kerasionalan penggunaan antibiotik pada pasien.

Selain pemilihan antibiotik, penggunaan insulin sebagai pengendalian gula darah pasien juga perlu diperhatikan dalam penggobatan pasien ulkus diabetikum dimana kadar glukosa darah yang tinggi beresiko meningkatkan keparahan pada ulkus. Pada pasien P4 diketahui pasien menderita hipoglikemia dengan kadar gula darah sewaktu $55 \mathrm{mg} / \mathrm{dl}$. Dari riwayat penyakit pasien diketahui telah menderita diabetes melitus dan hipertensi selama satu tahun. Pasien aktif merokok dan menggunakan insulin.

Menurut Liu dkk bahwa nikotin dalam rokok dapat meningkatkan resistensi reseptor insulin dan menurunkan sekresi insulin pada sel $\beta$ pankreas sehingga meningkatkan resiko diabetes melitus [28]. Pemahaman pasien dalam menggunakan insulin akan membantu dalam mencapai tujuan terapi. Kesalahan terapi insulin dapat menjadi 
masalah klinis hal ini disebabkan karena keterbatasan dalam keterampilan (skill based), cara (rule based) dan pengetahuan (knowledge based) dalam penggunaan insulin [2]. Sehingga pasien menggunakan insulin tidak sesuai dengan cara pakai dan dosisnya akibat kurangnya keterampilan dan pengetahuan pasien yang menyebabkan penurunan kadar glukosa darah secara drastis.

Hasil evaluasi antibiotik yang telah dilakukan, diperoleh ketepatan indikasi antibiotik 100\% dengan tepat pasien $100 \%$. Antibiotik diberikan sesuai dengan penyebab infeksi dan tidak kontraindikasi dengan keadaan patologi dan fisiologi pasien. Tepat pengobatan 89,28\% karena hasil kultur tiga pasien P7, P9 dan P10 didapatkan antibiotik terapi empiris seperti Seftriakson, Siprofloksasin dan Sefotaksim yang diberikan telah resisten. Keterbatasan hasil kultur bakteri sehingga hanya tiga pasien yang ditemukan tidak tepat obat.

Ketepatan regimen dosis diperoleh 54,17\% tepat dosis karena beberapa antibiotik, frekuensi pemberian yang tidak tepat dan lamanya pemberian tidak sesuai dengan yang diindikasikan seperti Seftazidim yang diresepkan dua kali sehari dimana seharusnya Seftazidim diresepkan 3 kali sehari untuk pengobatan infeksi ringan, sedang hingga berat pada pasien dengan penyakit pneumonia maupun untuk infeksi ringan dan sedang untuk pasien ulkus [29]. Selain itu, Seftriakson yang seharusnya diberikan 3-4 hari untuk terapi empiris diberikan 5-7 hari atau lebih.

Ketepatan penggunaan antibiotik terhadap potensi interaksi obat lainya diperoleh sebanyak 67,85\% tidak berpotensi terjadi interaksi. Dari 28 pasien yang mendapat terapi antibiotik ada 9 pasien yang mengalami potensi interaksi obat. Bentuk interaksi obat yang paling banyak terjadi yaitu golongan antibiotik flurokuinolon dengan insulin aspartat dimana Levofloksasin dan Siprofloksasin dapat meningkatkan efek dari Novorapid secara farmakodinamik yang dapat menyebabkan hipoglikemia atau hiperglikemia pada pasien sehingga pemberiannya harus dimonitoring. Selain itu, interaksi antara Metronidazol dengan Simvastatin dapat meningkatkan efek Simvastatin pada intestinal secara farmakokinetik setelah terjadinya metabolisme menyebabkan aktifitas Simvastatin didalam tubuh meningkat. Sedangkan efek dari Seftriakson dengan Lasix dapat meningkatkan risiko nefrotoksik karena kadar Lasix meningkat [29].

Hubungan karakteristik klinis (lama dirawat) terhadap clinical outcome pada pasien ulkus diabetikum dengan uji chi square didapatkan hubungan yang bermakna dengan nilai $\mathrm{p}=0,029$ dimana $\mathrm{p}<0,05$. Lama rawat yang singkat menunjukkan kondisi pasien yang membaik.
Hasil ini sejalan dengan penelitian Yunus di ETN Center Makassar 2015 dimana semakin parah kondisi pasien yang dipengaruhi oleh tingkat keparahan infeksi luka maka akan semakin lama waktu perawatan yang dibutuhkan dalam proses penyembuhannya kerena memerlukan penanganan dan tindakan yang lebih lanjut [30].

Sedangkan antara karakteristik klinis (lama menderita DM, riwayat tukak, tingkat keparahan infeksi, clinical outcome) terhadap clinical outcome dan rasionalitas antibiotik didapatkan hubungan yang tidak bermakna dengan nilai $\mathrm{p}$ $>0,05$. Ini menunjukkan bahwa karakteristik demografi dan karakteristik klinis tidak memiliki hubungan yang signifikan terhadap clinical outcome dan kerasionalan antibiotik yang terjadi pada pasien ulkus diabetikum.

\section{Keterbatasan Penelitian}

Penelitian yang dilakukan memiliki keterbatasan karena hanya 3 dari 28 pasien yang dilakukan uji kultur bakteri dan sensitivitas terhadap antibiotik. Di IRNA Penyakit Dalam RSUP DR. M. Djamil Padang untuk pengobatan pasien ulkus diabetikum tidak memiliki pedoman khusus dalam pengobatan. Sehingga pengobatan hanya berdasarkan pengalaman dari kasus yang ada sebelumnya.

\section{Kesimpulan}

Karakteristik klinis pada pasien ulkus diabetikum adalah lama menderita DM $<10$ tahun $(71,43 \%)$ dengan tingkat keparahan infeksi berat $(71,43 \%)$ dan clinical outcome pasien membaik (71,43\%). Pola penggunaan antibiotik pada pasien ulkus diabetikum terbanyak digunakan adalah kombinasi seftriakson dan metronidazol $(26,1 \%)$. Kerasionalan antibiotik yang digunakan pasien ulkus diabetikum diperoleh tepat indikasi (100\%), tepat pasien $(100 \%)$, tepat obat $(89,28 \%)$, tepat regimen dosis $(57,14 \%)$, dan $67,85 \%$ tidak berpotensi interaksi obat. Terdapat hubungan yang tidak signifikan antara karakteristik demografi dan karakteristik klinis terhadap rasionalitas antibiotik ( $>>0.05)$ Sehingga dapat disimpulkan bahwa penggunaan antibiotik pada pasien ulkus diabetikum belum rasional.

\section{Referensi}

[1]. International of Diabetic Federation. Diabetes Atlas (7 $7^{\text {th }}$ Edition); 2017.

[2]. Perkumpulan Endokrinologi Indonesia. Konsensus Pengendalian dan Pencegahan Diabetes Melitus Tipe 2 di Indonesia . Jakarta: PB PERKENI; 2015.

[3]. Kartika, RW. Pengelolaan Gangren Kaki Diabetik. Jakarta: Continuing Medical Education. 2017;44(1). 
[4]. Departemen Kesehatan Republik Indonesia. Pedoman Pengendalian Diabetes Melitus dan Penyakit Metabolik. Jakarta: Direktorat Jenderal Pengendalian Penyakit dan Penyehatan Lingkungan; 2008.

[5]. Departemen Kesehatan Republik Indonesia. Riset Kesehatan Dasar. Jakarta: Badan Penelitian dan Pengembangan Kesehatan; 2013.

[6]. Lipsky BA, Berendt AR, Cornia PB, Pile JC, Peters EJ, Armstrong DG, Deery HG, Embil JM, Joseph WS, Karchmer AW, Pinzur MS, Senneville E. Infectious disease society of America clinical practice guideline for the diagnosis and treatment of diabetic foot infections. IDSA Guidelines. 2012:132-147.

[7]. Langi, Yuanita A. Penetalaksanaan Ulkus Diabetes Secara Terpadu. Jurnal Biomedik. 2011;3(2):95-101.

[8]. Lirijani B, Hasani RS. Overview of diabetic foot; Novel treatments in diabetic foot ulcer. Endocrinology and Metabolism Research Center (EMRC). Iran: Tehran University of Medical Sciences. 2008;16(1).

[9]. Yekta Z, Pourali R, Nezhadrahim R, Ravanyar L, Ghasemi M. Clinical and behavioral factors associated with management outcome in hospitalized patients with diabetic foot ulcer. Dove Press Journal; 2011.

[10]. Chamber,HF. Antimicrobial agents: Goodman and Gilman's The Pharmacological Basic of Therapeutic Eleventh Edition. New York: The Mc Graw Hill Co; 2006.

[11]. Peraturan Menteri Kesehatan Republik Indonesia. Pedoman Umum Penggunaan Antibiotik. Jakarta; 2011.

[12]. Agistia N, Muchtar H, Nasif H. Efektifitas Antibiotik pada pasien ulkus kaki diabetik. Jurnal Sains Farmasi dan Klinis. 2017;4(2):43-48.

[13]. Decroli E, Jazil K, Asman M, dan Syafril S. Profil Ulkus Diabetik Pada Penderita Rawat Inap Bagian Penyakit Dalam RSUP Dr. M. Djamil Padang. Majalah Kedokteran Indonesia. 2008;58(1):1-7.

[14]. Hatanta, A. Kajian Penggunaan Antibiotik Pada Pasien Infeksi Ulkus Kaki Diabetik IRNA Penyakit Dalam RSUP Dr. M. Djamil Padang. (Tesis). Universitas Andalas. Padang; 2013.

[15]. Nafilataini. Evaluasi Penggunaan Antibiotik Pada Pasien Ulkus Diabetikum di IRNA Penyakit Dalam RSUP Dr. M. Djamil Padang. (Skripsi). Universitas Andalas. Padang; 2017.

[16]. Hastuti Rini Tri. Faktor-faktor Risiko Ulkus Diabetika Pada Penderita Diabetes Melitus (Studi Kasus di RSUD Dr.Moewardi Surakarta). (Tesis). Universitas Diponegoro. Semarang;2008.
[17]. Norgren L, Hiatt WR, Dormandy JA, Nehler MR, Harris KA, Fowkes. Inter Society Consensus for the Management of Peripheral Arterial Disease. Journal of Vascular Surgery. 2007: 45(1).

[18]. Jain, AK. A new Classification of diabetic foot complications: A simple and effective teaching tool. Journal of Diabetic Foot Complication. 2012;1(1):1-5.

[19]. Rochman, W.Diabetes Mellitus pada Usia Lanjut. Jilid III. Edisi kelima. Jakarta: Balai Penerbit FK UI; 2009.

[20]. Nugroho W. Keperawatan Gerontik dan Geriatrik Edisi III. Jakarta: ECG. 2008.

[21]. Nezhad A, Moharban G, Parizadeh MR, Safarian M, Esmaelli H, Khodaee G, Hosseini J, Albasti Z. Prevalence of type 2 diabetes mellitus in iran and its relationship with gender, urbanisasion, education, marital status, and occupation. Singapore Medical Journal. 2008;49(7);571.

[22]. Brown AF, Susan LE, John P, Weinberger M. Socioeconomic position and health among person with diabetes mellitus: A Conseptual Framework and Review of Literature. John Hopkins Bloomber School of Public Health. 2012: 2(10).

[23]. Frykberg RG. Diabetic foot ulcer: pathogenesis and management. Am Fam Physician. 2002;66(9):1655-1662.

[24]. Akbar GT, Jazil K, Dewi A. Pola bakteri dan resistensi antibiotik pada ulkus diabetika grade dua di rsud arifin achmad periode 2012.JOM. 2014:1(2).

[25]. Katzung B, Susan B, Masters, Anthony J. Basic of Clinical Pharmacologiy 10th edition. USA: McGraw-Hill Companies; 2010.

[26]. Leekha S. General Principles of Antimicrobial Theraphy. Mayo Clinic Proceedings. 2011: 86(2).

[27]. Brunton L, Keith, Donald L. Goodman \& Gillman's Manual of Pharmacology and Therapeutics. Diterjemahkan oleh July Manurung. Jakarta: ECG; 2010.

[28]. Liu T, Chen W, David SP, Tyndale RF. Interaction between heavy smoking and CYP2A6 Genotypes on type 2 Diabetes and its possible pathways. Europian Journal of Endocrinology. 2011: 165(6);961-967.

[29]. Medscape Application. 2018

[30]. Yunus B. Faktor-faktor yang Mempengaruhi Lama Penyembuhan Luka Pada Pasien Ulkus Diabetikum di Rumah Perawatan ETN Center Makassar Tahun 2014. (Skripsi). FK UIN Alaudin Makassar: 2015. Copyright $\odot 2018$ The author(s). You are free to share (copy and redistribute the material in any medium or format) and adapt (remix, transform, and build upon the
material for any purpose, even commercially) under the following terms: Attribution - You must give appropriate credit, provide a link to the license, and indicate if material for any purpose, even commercially) under the following terms: Attribution - You must give appropriate credit, provide a link to the license, and indicate if changes were made. You may do so in any reasonable manner, but not in any way that suggests the licensor endorses you or your use; ShareAlike - If you remix,
transform, or build upon the material, you must distribute your contributions under the same license as the original (https://creativecommons.org/licenses/by-sa/4.0/) 